\title{
CAMPUR KODE DAN ALIH KODE PADA RUBRIK “ NAH INI DIA" DALAM HARIAN POS KOTA
}

\author{
Tadjuddin Nur \\ Fakultas Sastra Universitas Nasional \\ Tadjuddin.kwardadki@gmail.com
}

\begin{abstract}
ABSTRAK
Peneltian ini merupakan penelitian deskriftif kualitatif yang mengkaji fenomena kebahasaan dengan pendekatan sosiolingistik. Tujuan penelitian ini adalah: (1) mendeskripsikan bentuk capur kode pada rubrik "Nah Ini Dia" harian Poskota; (2) mendeskripsikan bentuk alih kode pada rubrik "Nah Ini Dia" harian Poskota; (3) mengidentifikasi fungsi penggunaan campur kode dan alih kode pada rubrik "Nah Ini Dia" harian Poskota. Sampel yang diambil dalam penelitian ini adalah wacana pada rubrik "Nah Ini Dia" harian Poskota Edisi April 2019. Sumber data berasal dari dokumen dan informan. Hasil penelitian ini adalah : bentuk campur kode pada rubrik "Nah Ini Dia" harian Poskota terdiri atas (1) kata, (2) frase, (3) baster (4) reduplkasi, (5) Idiom dan (6) klausa. Bentuk alih kode pada rubrik "Nah Ini Dia" harian Poskota terdiri atas Ragam bahasa formal beralih ke ragam bahasa santai. Sementara fungsi campur kode dan alih kode dari rubrik "Nah Ini Dia" harian Poskota adalah: (1) untuk menciptakan suasana santai dan humoris, (2) untuk memberikan dakwah dan nasehat, (3) untuk memberikan pemahaman budaya, dan (4) untuk menyampaikan pesan politik.
\end{abstract}

Kata kunci: sosiolinguistik, bahasa, campur kode, alih kode, rubrik

\section{ABSTRACT}

This research is a qualitative descriptive study that examines linguistic phenomena with a sociolinguistic approach. This study aims at describing the type of code mixing in the rubrics "Nah Ini Dia" of Poskota daily, describing the type of code switching in the rubric "Nah Ini Dia" of Poskota daily, and identifying the function of code mixing and code switching uses in the rubric of "Nah Ini Dia" of Poskota daily. The sample taken in this study is the discourse in the rubric of "Nah Ini Dia" of Poskota daily, edition of April 2019. The sources of data come from documents and informants. The results of this study are the type of code mixing in the rubric of "Nah Ini Dia" Poskota daily consists of (1) words, (2) phrases, (3) baster (4) reduplication, (5) idioms and (6) clauses. The type of code switching in the "nah Ini Dia" rubrik of Poskota daily consists of a variety of formal languages switch to a variety of casual languages. While the function of code mixing and code switching uses from the rubric of "Nah Ini Dia" Poskota daily are creating a relaxed and humorous atmosphere, providing missionary and advice, providing cultural understanding, and delivering political messages.

Keywords: sociolinguistics, language, code mixing, code switching, rubrics

\section{PENDAHULUAN}

\section{Latar belakang}

Salah satu konsep dasar di dalam sosiolinguistik yang harus kita pahami adalah gagasan tentang bahasa dan ragam (variasi) bahasa. Sudah sering disebut kata "bahasa", seolah-olah sudah dipahami benar apa itu bahasa. Padahal, sebenarnya masih banyak hal yang harus diselesaikan dalam hubungannya dengan istilah bahasa itu. Apalagi kalau diingat, bahasa itu 
bukan sesuatu yang monolitik, yang tunggal; jadi bahasa mesti mengandung keragaman.(Sumarsono:2017). Kridalaksana (1993) mengatakan bahwa sosiolinguistik adalah cabang linguistik yang mempelajari hubungan dan saling pengaruh antarprilaku bahasa dan prilaku sosial. Sosiolinguistik bukan saja menyoroti masalah bahasa dalam suatu masyarakat melainkan bahasa dengan prilaku sosial.

Komunikasi adalah proses pertukaran informasi antarindividual melaui sistem simbol, tanda, atau tingkah laku yang umum. Dari batasan tersebut, maka kita dapatkan tiga komponen yang harus ada dalam setiap proses komunikasi, yaitu (1) pihak yang berkomunikasi, yakni pengirim dan penerima informasi yang dikomuniaksikan, yang lazim disebut partisipan; (2) informasi yang dikomunkasikan; (3) alat yang digunakan dalam komunikasi itu (Chaer:2010).

Dalam berkomunikasi dapat dilakukan dengan lisan atau tulisan. Salah satu komunikasi dengan tulisan adalah bahasa Jurnalistik. Pengertian bahasa jurnalistik adalah gaya bahasa yang digunakan wartawan dalam menulis berita. Sebutan lain bahasa jurnalistik adalah bahasa media, bahasa pers, dan bahasa koran. Dengan menggunakan bahasa khas wartawan ini, tulisan di media menjadi ringkas, padat, mudah dipahami, efektif, efisien, dan enak dibaca. Wartawan dapat meringkas baanyak fakta dan memadatkan maknaa dalam sebuah kata atau kalimat (Romeltea.Com).

\section{Rumusan Masalah}

Berdasarkan latar belakang di atas, rumusan masalah dalam penelitian ini sebagai berikut.

1. Bagaimana bentuk capur kode pada rubrik "Nah Ini Dia” harian Poskota?

2. Bagaimana bentuk alih kode pada rubrik "Nah Ini Dia" harian Poskota?

3. Bagaimana fungsi penggunaan campur kode dan alih kode pada rubrik "Nah Ini Dia" harian Poskota?

\section{Tujuan Penelitian}

Penelitian ini bertujuan untuk:

1. mendeskripsikan bentuk capur kode pada rubrik "Nah Ini Dia" harian Poskota;

2. mendeskripsikan bentuk alih kode pada rubrik "Nah Ini Dia" harian Poskota;

3. mengidentifikasi fungsi penggunaan campur kode dan alih kode pada rubrik "Nah Ini Dia" harian Poskota.

\section{Tinjauan Pustaka}

Campur kode merupakan salah satu aspek saling ketergantungan bahasa di dalam masyarakat bilingual (dwibahasa). Jadi, hampir tidak mungkin di dalam masyarakat bilingual seorang penutur menggunakan satu bahasa secara mutlak tanpa sedikitpun memanfaatkan bahasa atau unsur bahasa lain. Di Indonesia gejala campur kode tersebut sering disebut dengan 'gado-gado' yang diibaratkan dengan sajian gado-gado, yakni campuran dari bermacam-macam sayuran. Realita yang terjadi di Indonesia yaitu pencampuran penggunaan bahasa Indonesia dengan bahasa daerah tertentu. Nababan (1993:32) berpendapat bahwa ciri yang menonjol dalam campur kode adalah kesantaian atau situasi informal. Dalam situasi yang formal jarang terdapat campur kode. Suwito (1985:78-79) menyebutkan beberapa macam campur kode yang berdasarkan unsur-unsur kebahasaan yang terlibat di dalamnya terdiri dari penyisipan unsurunsur yang berwujud kata; penyisipan unsur-unsur yang berwujud frasa; penyisipan unsur-unsur 
yang berwujud bentuk baster; penyisipan unsur-unsur yang berwujud pengulangan kata; penyisipan unsur-unsur yang berwujud ungkapan atau idiom; serta penyisipan unsur-unsur yang berwujud klausa.

Menurut Suwito (1985:79) tujuan yang hendak dicapai oleh penutur dalam tuturannya sangat menentukan pilihan bahasanya. Penutur melakukan campur kode ada tujuan-tujuan tertentu yang ingin dicapai oleh pemakai bahasa. Foley (dalam Mahsun, 2011:228) mengungkapkan bahwa gambaran tentang bahasa akan menunjukkan gambaran tentang kondisi sosial suatu masyarakat, begitu sebaliknya, gambaran tentang kondisi sosial satu masyarakat akan tercermin dalam bahasa yang mereka gunakan. Kontak bahasa yang terjadi dalam kehidupan masyarakat sehari-hari sebagai masyarakat tutur yang dwibahasa akan berpengaruh juga pada penyampaian informasi dalam sebuah surat kabar, apalagi dengan latar belakang budaya yang sangat mengakar kuat dalam diri setiap masyarakatnya, dalam hal ini penggunaan bahasa Indonesia yang terpengaruh oleh bahasa daerah mudah sekali menyebar melalui media massa.

Penelitian Yassi (2001) menemukan bahwa jenos kombinasi segmen dalam kalimat campur kode bahasa Indonesia dan bahasa Inggeris yang paling mendominasi adalah bentuk verba, yaitu sebanyak $18 \%$. Verba tersebut berkombinasi dengan didahului oleh pronomina atau frasa nominal dan diikuti oleh frasa prefosisional. Selain itu, alih kode bahasa Indonesia-bahasa Inggeris umumnya terjadi paadaa tingkat konsituen yang lebih kecil seperti kata dan paling jauh paada tingkaat frasa dn terlihat bahwa nomina dan frasa nominal mendominasi unsur-unsur lainnya, yakni sekitar $40 \%$ dari sampel yang ada.

Appel (dalam Chaer,2010:107) mendefinisikan alih kode itu sebagai,"gejala peralihan pemakaian bahasa karena berubahnya situasi". Berbeda dengan Appel yang mengatakan alih kode itu terjadi karena berubahnya antar bahasa, maka Hymes (dalam Chaer,2010:107-108) menyatakan alih kode bukan hanya terjadi antarbahasa, tetapi dapat juga terjadi antara ragamragam atau gaya-gaya yang terdapat dalam satu bahasa.

Mengenai ciri dari alih kode, Poedjosoedarmo (1976) mengemukakan bahwa peristiwa alih kode melibatkan peralihan kalimat. Hymes (dalam Rahardi, 2001:20) membagi alih kode berdasarkan sifatnya menjadi dua yaitu alih kode intern (internal code switching) dan alih kode ekstern (external code switching). Alih kode intern yakni terjadi antara bahas daerah dalam satu bahasa nasional, antar dialek dalam satu bahasa daerah atau beberapa ragam dan gaya yang terdapat dalam satu dialek. Adapun yang dimaksud dengan alih kode ekstern adalah apabila yang terjadi antara bahasa Indnesia dengan bahasa asing.

Penyebab terjadinya alih kode dapat kita cermati pendapat yang dikemukakan Fishman (dalam Chaer, 2010:108) yaitu "siapa berbicara, dengan bahasa apa, kepada siapa, kapan, dan dengan tujuan apa". Dalam berbagai kepustakaan linguistik secara umum penyebab alih kode itu disebutkan antara lain adalah (1) pembicara atau penutur, (2) pendengar atau lawan tutur, (3) perubahan situasi dengan hadirnya orang ke tiga, (4) perubahan dari formal ke informal atau sebaliknya, (5) perubahan topik pembicaraan.

Poskota yang didirikan oleh Harmoko (Menteri Penerangan Republik Indonesia saat itu) merupakan salah satu koran independen yang terbit di Ibukota Jakarta. Harian Poskota adalah surat kabar yang memuat peristiwa aktual yang terjadi di Indonesia. Harian Poskota sendiri merupakan salah satu dari sekian banyak surat kabar yang terbit di Jakarta dan tersebar di Jakarta dan sekitarnya. Setiap hari surat kabar ini terbit dengan 12 halaman ditambah dengan halaman- 
halaman tambahan yang berisi berita-berita, berbagai macam kolom, artikel, rubrik, olah raga, selebritis, dan ruang iklan.

Salah satu rubrik yang terdapat dalam harian ini adalah Rubrik "Nah Ini Dia" (NID). Rubrik NID sampai sekarang ini masih menjadi aset penting harian Poskota. Awalnya rubrik NID yang diasuh oleh Gunarso TS adalah kolom berita singkat daerah. Kemudian berkembang menjadi tulisan di halan depan menjadi tulisan yang cukup panjang. Rubrik yang dimuai tahun 1987 ini menjadi pengobat ketegangan pembaca harian Poskota karena dahulu berita yang disajikan Poskota kebanyakan masalah kriminal dan politik. Setelah dipusingkan dan ditegangkan dengan berita-berita kriminal dan politik ada obat penyegarnya, yakni ketika membaca rubrik NID, sehingga pembaca tidak selalu serius dan dapat tertawa.

Rubrik NID menginformasikan mengenai kejahatan yang terjadi di seluruh Indonesia yang dikemas kembali dalam konsep dan format yang berbeda dengan rubrik-rubrik yang lain dengan menimbulkan kesan humor. Awal mulanya di harian Poskota terdapat kolom kecil yakni berita singkat daerah, yang mengulas berita-berita di daerah yang kemudian berkembang menjadi rubrik NID. Sumber berita yang dijadikan ide pokok dari rubrik NID adalah peristiwa-peristiwa kriminal yang berada di daerah, khususnya dengan topik kejahatan asusila (perselingkuhan, pencabulan, pemerkosaan, dan sebagainya).

Dengan kepiawaian pengasuhnya, rubrik NID sampai saat ini kehadirannya masih sangat ditunggu pembaca. Mengunakan gaya bahasa yang humoris kejadian kriminal yang terjadi di masyarakat tersaji dengan demikian baiknya. Pembaca dapat menikmati tulisan ini dengan santai walaupun temanya masalah-masalah kriminal.

\section{METODE PENELITIAN}

Penelitian ini merupakan penelitian deskriptif kualitatif yang mengkaji fenomena kebahasaan dengan pendekatan sosiolinguistik. Sampel yang diambil dalam penelitian ini adalah wacana pada rubrik "Nah Ini Dia " harian Poskota edisi bulan April tahun 2019. Sumber data berasal dari dokumen dan informan. Penelitian ini dilakukan untuk mengetahui bentuk dan fungsi pemakaian campur kode dan alih kode. Teknik pengumpulan data menggunakan tekknik baca catat dan wawancara mendalam dengan redaktur. Analsis data dalam penelitian ini menggunakan analisis data interaktif dan metode padan.

\section{HASIL PENELITIAN}

\section{Bentuk Campur Kode}

Kridalaksana (1993) menyatakan bahwa campur kode merupakan penggunaan satuan bahasa dari satu bahasa ke bahasa yang lain untuk memperluas gaya bahasa atau ragam bahasa, termasuk di dalamnya pemakaian kata, kalusa, idiom, sapaan. Wujud dari koponen tutur kode tidak pernah berwujud kalimat, melainkan hanya berwujud kata, frasa, idiom, bentuk baster, perulangan kata, dan klausa.

Berdasarkan unsur-unsur kebahasaan yang terlibat di dalamnya, Suwito (1985:92) membedakan campur kode menjadi beberapa macam antara lain : (1) penyisipan unsur-unsur yang berwujud kata, (2) penyisipan unsur-unsur yang berwujud frasa, (3) penyisipan unsur-unsur yang berwujud bentuk baster, (4) penyisipan unsur-unsur yang berwujud perulangan kata, (5) penyisipan unsur-unsur yang berwujud ungkapan atau idiom, dan (6) penyisipan unsur-unsur yang berwujud klausa. 
Pada rubrik "Nah Ini dia" harian Poskota edisi bulan April 2019, didapatkan sejumlah campur kode dari penyisipan berbagai unsur, seperti terlihat dalam tabel berikut.

\begin{tabular}{|l|l|l|l|l|l|l|l|}
\hline $\begin{array}{l}\text { EDISI } \\
\text { TGL }\end{array}$ & Kata & Frasa & Baster & $\begin{array}{l}\text { Kata } \\
\text { ulang }\end{array}$ & $\begin{array}{l}\text { Ungkapan/ } \\
\text { Idiom }\end{array}$ & Klausa & Jumlah \\
\hline $1 / 4 / 2019$ & 17 & 4 & 2 & 1 & 8 & 4 & 36 \\
\hline $4 / 4 / 2019$ & 4 & 5 & - & 3 & 16 & 4 & 32 \\
\hline $5 / 4 / 2019$ & 21 & 2 & 1 & - & 7 & 4 & 36 \\
\hline $11 / 4 / 2019$ & 17 & 2 & - & 3 & 5 & 1 & 28 \\
\hline $14 / 4 / 2019$ & 16 & 1 & - & 4 & 4 & - & 25 \\
\hline $21 / 4 / 2019$ & 31 & 2 & - & 3 & 6 & 2 & 44 \\
\hline $24 / 4 / 2019$ & 14 & 2 & - & 3 & 6 & 6 & 31 \\
\hline Jumlah & 120 & 18 & 3 & 17 & 52 & 21 & 232 \\
\hline
\end{tabular}

Pemakaian campur kode yang berwujud kata dapat dilihat pada contoh data berikut.

Jika ada ayah tiri celamitan, salah satunya Markadi,39, dari Tegalsari, Surabaya. (NID, Ayah Tiri... / 1 April 2019)

Kata celamitan berasal dari bahasa Betawi yang artinya suka iseng. Campur kode ini merupakan campur kode intern terjadi antara bahasa Indonesia dan bahasa Betawi.

Sikap Didu bikin tambah jengkel Roky, wong mau dikasih enak kok tidak mau. (NID, Gara Gara Nagih Utang... / 5 April 2019)

Kata jengkel , wong, padanan kata "kesal" dan "orang”. Berasal dari bahasa Jawa. Campur kode ini merupakan campur kode intern antara bahasa Indonesia dengan bahasa Jawa.

Pemakaian campur kode yang berwujud frasa dapat dilihat pada contoh data berikut.

Perempuan super gatel ini adalah Ny. Royahani warga Sumedang. (NID, Berani Selingkuh.../4 April 2019) 
Contoh frasa super gatel dalam kalimat di atas merupakan campur kode intern karena terjadi antara bahasa serumpun yaitu bahasa Indonesia dan bahasa Melayu dialek Betawi.

Kamsiah baru sadar sekarang bahwa dirinya salah gaul, tetapi sudah kadung digauli. (NID, Habis Tidur..../11 April 2019)

Frasa salah gaul dan kadung diagauli merupakan peralihan bahasa santai atau nonformal. Campur kode ini termasuk campur kode intern karena terjadi dari bahasa serumpun.

Pemakaian campur kode yang berwujud baster dapat dilihat pada contoh data berikut.

Kalau duit, oleh Markadi pasti di mark up, bukannya diperkecil. (NID, Ayah Tiri.../1 April 2019)

Contoh kata dimarkup merupakan baster yaitu kata asing "markup" yang diberikan imbuhan bahasa Indonesia " $d i$-". Campur kode ini merupakan campur kode ekstern karena terjadi antara bahasa Indonesia dan bahasa Inggris.

Roky langsung telepon Didu, untuk mengklarifikasi. (NID, Gara-Gara Nagih .../5 April 2019)

Contoh kata mengklarifikasi merupakan baster yaitu kata asing "klarifikasi " yang diberikan imbuhan bahasa Indonesia "me-". Campur kode ini merupakan campur kode ekstern karena terjadi antara bahasa Indonesia dan bahasa Inggris.

Pemakaian campur kode yang berwujud kata ulang dapat dilihat pada contoh data berikut.

Maldani memang baru 44 tahun, jadi masih rosa-rosa macam Mbah Marijan. (NID, Habis Tidur .../11 April 2019)

Contoh kata ulang rosa-rosa merupakan campur kode intern karena terjadi antara bahasa serumpun yaitu bahasa Indonesia dengan bahasa Jawa.

Benar saja, saat digedor-gedor pintunya, Ridwan-Sainah keluar dengan pakaian awut-awutan. (NID, Sembilan Bulan.../14 April 2019)

Contoh kata ulang digedor-gedor dan awut-awutan merupakan campur kode intern karena terjadi antara bahasa serumpun yaitu bahasa Indonesia dengan Melayu dialek Betawi.

Pemakaian campur kode yang berwujud ungkapan/idiom dapat dilihat pada contoh data berikut.

Rocky ikut pula tersinggung demi mendengar istrinya dicap sebagai the butterfly of night. (NID, Gara-Gara Nagih .../5 April 2019)

Contoh ungkapan /idiom the butterfly of night yang berarti "wanita nakal" merupakan campur kode ekstern karena terjadi antara bahasa Indonesia dan bahasa Inggeris. 
Sebagai bukti solidaritas antar warga, mereka pun ikut saja bak kerbau dicocok hidung. (NID, Bukan Kiageng .../24 April 2019)

Contoh ungkapan /idiom bak kerbau dicocok hidung yang berarti "menurut saja" merupakan campur kode intern karena terjadi antara bahasa Indonesia dan Melayu Minang .

Pemakaian campur kode yang berwujud klausa dapat dilihat pada contoh data berikut.

Karuan saja istri Begy melabrak si sepupu gatelan, bahkan kemudian minta cerai. (NID, Menjadi Pemborong.../ 21 April 2019)

Contoh klausa si sepupu gatelan merupakan campur kode intern karena terjadi dari bahasa serumpun yaitu bahasa Indonesia dan dialek Betawi.

Nah, saat Kiageng Wonoboyo sungkem Panembahan Senopati sebagai tanda bakti menantu, kepala langsung dijedotin ke kursi dampar hingga tewas! (NID, Bukan Kiageng .../24 April 2019)

Contoh klausa Kiageng Wonoboyo sungkem merupakan campur kode intern karena terjadi dari bahasa serumpun yaitu bahasa Indonesia danbahasa Jawa.

\section{Bentuk Alih Kode}

Hymes (dalam Chaer, 2010:107) menyatakan alih kode itu bukan hanya terjadi antar bahasa, tetapi dapat juga terjadi antar ragam-ragam atau gaya-gaya yang terdapat dalam satu bahasa. Peristiwa pergantian bahasa terjadi dari perubahan ragam santai menjadi ragam resmi, atau juga ragam resmi ke ragam santai, inilah yang disebut peristiwa alih kode di dalam sosiolinguistik.

Berdasarkan data penelitian ditemukan Pemakaian alih kode dari ragam resmi atau formal ke ragam bahasa santai atau informal, seperti pada contoh data temuan berikut ini.

Demikianlah, terlalu sering kirim foto bugil kepada kedua PIL-nya, sekali waktu Rohyani menyebut nama Nursal sebagai Manurung. Karuan saja Nursal tahu bahwa Rohayani punya PIL yang lain. Dia marah besar, kok kaya capres saja, ada no.01 ada pula no. 02. Lalu kapan debatnya, wong selama ini Nursal tak pernah dipertemukan dengan Manurung. Memangnya KPU mau ngurusin beginian? (NID, Berani Selingkuh.../4April 2019)

Dari data temuan di atas terjadi peralihan ragam bahasa yang semula mengguakan ragam bahasa formal kemudian berubah menjadi ragam bahasa santai.

Tapi Didu tak kunjung datang. Dia takut ditemu kuwuk ( disergap untuk dianiaya). Dalam logika akal sehatnya, mana mungkin orang punya kebaikan tingkat dewa. Hanya Prabu Puntadewa wayang kulit yang mau berikan istrinya kepada lelaki lain. Ketimbang nanti malah datang dan dipenggal kepalanya, mending absen. Soalnya, hidup tanpa kepala, bagaimana kalau pakai kupluk untuk pergi kenduri ? ( NID, Gara-Gara Nagih.../5 April 2019) 
Dari data temuan di atas terjadi peralihan ragam bahasa yang semula mengguakan ragam bahasa formal kemudian berubah menjadi ragam bahasa santai.

\section{Fungsi Campur Kode dan Alih Kode}

Sehubungan dengan faktor-faktor penyebab terjadinya campur kode, maka dalam peristiwa tutur yang memegang peranan penting adalah (1) lupa bahasa daerah, (2) penegasan atau memperjelas, dan (3) pokok pembicaraan. Fungsi campur kode adalah (1) sebagai acuan unsur yang tidak(kurang) dipahami di dalam bahasa yang digunakan, kebanyakan terjadi karena pembicaraan tidak mengetahui suatu kata dalam bahasa lain, (2) berfungsi ekspresi, pembicaraan menekankan identitas campur kode melalui penggunaan dan bahasa yang sama, (3) berfungsi sebagai humor atau permainan yang sangat berperan dalam masyarakat bilingual.

Menurut Chaer (2010:114) di dalam campur kode ada sebuah kode utama atau kode dasar yang digunakan dan memiliki fungsi dan keotonomiannya sedangkan alih kode setiap bahasa atau ragam bahasa yang digunakan masih memiliki otonomi masing-masing, sedangkan kodekode lain yang terlibat hanyalah berupa serpiahan-serpihan (pieces) saja, tanpa fungsi atau keotonomiannya sebagai sebuah kode.

Fungsi alih kode adalah (1) sebagai acuan unsur yang kurang dipahami di dalam bahasa yang digunakan (2) berfungsi direktif, (3) berfungsi ekspresi, (4) berfungsi untuk menunjukkan perubahan konverensi, (5) berfungsi sebagai matabahasa, (6) berfungsi sebagai humor atau permainan.

Agak berbeda dengan fungsi-fungsi campur kode dan alih kode dari uraian di atas, fungsi campur kode dan alih kode dalam rubrik NID harian Poskota sebagaimana yang disampaikan pengasuh rubrik NID adalah: (1) Berfungsi sebagai menciptakan suasana santai, sehingga pembaca tidak terlalu tegang. (3) Berfungsi untuk menyampaikan dakwah atau nasehat-nasehat. (3) Berfungsi untuk mengenalkan peristiwa budaya daerah. (4) Berfungsi untuk berbicara politik.

Fungsi untuk menciptakan suasana santai.

Demikianlah, terlalu sering kirim foto bugil kepada kedua PIL-nya, sekali waktu Rohayani menyebut nama Nursal sebagai Manurung. Karuan saja Nursal jadi tahu bahwa Rohayani punya PIL yang lain. Dia marah besar, kok kaya capres saja, ada No. 01 ada pula No. 02. Lalu kapan debatnya, wong selama ini Nursal tak pernah dipertemukan dengan Manurung. Memangnya KPU mau ngurusin beginian? (NID, Berani Selingkuh .../ 4 April 2019)

Fungsi sebagai penyampaian dakwah atau nasehat

Banyak orang tak bisa bersyukur atas segala karunia Ilahi atasnya. Sudah punya suami yang sukses, mata masih jelalatan mencari lelaki lain. Itulah akibatnya jika nikmat iman dikalahkan oleh nikmat seks. Barang baik dilepaskan, justru ngopeni barang busuk yang kelihatannya baik. Padahal Allah sudah mengingatkan lewat firmannya : Barang yang kamu sukai belum tentu membawa kebaikan untukmu (surat Albaqaarah: 216) (NID, Habis Tidur.../11 April 2019)

Fungsi sebagai pengenalan peristiwa budaya daerah

Dalam sejarah Mataram dikisahkan, Kiageng Wonoboyo dari kadipaten Manggir memberontak pada raja Mataram, Penembahan Senopati. Untuk menaklukannya, 
Adipati Mangir itu dipancing dengan kecantikan putrinya, Retna Pambayun. Tak tahu bahwa gadis itu putri raja Mataram, dikawinilah. Setelah hamil, baru Pembayun buka kartu. Nah, saat kiageng Wonoboyo sungkem Panembahan Senopati sebagai tanda bakti menantu, kepala langsung dijedotin ke kursi dampar hingga tewas. Dhani warga gunung Mas, Kalteng, nasibnya sungguh mirip Kiageng Mangir dari Mataram tersebut. Bedanya Kiageng Mangir masalah pembangkangan negara, sedangkan Dhani hanya perkara keributan dalam keluarga. Kebetulan dia lelaki temperamental, sehingga pada istri berani pakai ngancam-ngancam segala. (NID, Bukan Kiageng Mangir.../24 April 2019)

Fungsi sebagai pembicaraan politik

Sebagai politisi kelas akar rumput, paasangan Mahmudi, 36, -Fadilah,30, benarbenar militan. Gara-gara suami bela capres Jokowi dan Fadilah pro Prabowo, mereka tak pernah akur dalam rumah tangga. Dampaknya sampai kemana-mana, sehingga Mahmudi yang habis kesabarannya terpaksa menceraikan Fadilah. Sebagai ormas, Nahdatul ulama dan Muhammadiyah bersikap netral dalam Pilpres. Tapi anggotanya, bebas mau memilih Jokowi atau Prabowo. Karena itulah NU yang umatnya mayoritas dukung capres No. 01, banyak pula yang dukung capres No.02. Begitulah pula sebaliknya. Muhammadiyah yang kelihatannya pro Prabowo, umatnya juga tak sedikit yang njepluk (keluar) dukung Jokowi. ( NID, Berbeda Dukungan .../20 April 2019)

\section{SIMPULAN}

Berdasarkan hasil analisis dan pembahasan di atas, peneltian mengenai bentuk dan fungsi campur kode dan alih kode pada rubrik NID harian Poskota, dapat disimpulkan sebagai berikut.

Bentuk campur kode pada rubrik NID harian Poskota yaitu berwujud (1) kata, (2) Frasa, (3) baster, (4) reduplikasi, (5) idiom, dan (6) klausa. Bentuk campur kode yang dominan adalah bentuk kata dan idiom.

Bentuk alih kode pada rubrik NID harian Poskota adalah dari ragam bahasa resmi atau formal ke ragam bahasa non formal atau santai. Ragam bahasa ini selalu bercampur atau istilahnya "gado-gado".

Fungsi pemakaian bentuk campur kode dan alih kode pada rubrik NID harian Poskota adalah: (1) Untuk menciptakan suasana santai agar pembaca tidak terlalu teagang. (2) Untuk menyampaikan pesan-pesan dakwah atau nasihat. (3) Untuk menyampaikan dan mengenalkan cerita budaya daerah. (4) Untuk menyampaikan pesan-pesan politik. 


\section{DAFTAR PUSTAKA}

Chaer, A.1995. Linguisti Umum. Jakarta: Renika Cipta. . 2010. Sosiolinguistik: Perkenalan Awal. Jakarta: Renika Cipta.

Kridalaksana, H.1993. Kamus Linguistik. Jakarta: Gramedia Pustaka Utama.

Yassi, A.H. 2016. Code Switching. As A Communication Strategy. Yogyakaarta: Trust Media

Mahsun. 2011. Metode Penelitian Bahasa: Tahapan Strategi, Metode, dan Tekniknya. Jakarta: Rajawali Press.

Nababan, P.W.J. 1993. Sosiolinguistik Suatu Pengantar. Jakarta: Gramedia Pustaka Utama.

Poedjosoedarmo,S. 1976. Pengaruh Bahasa Indonesia terhadap Bahasa Jawa. Stensilan.

Rahardi, K. 2011. Sosiolinguistik, Kode dan Alih kode. Yogyakarta: Pustaka Pelajar.

Sumarsono. 2017. Sosiolinguistik. Yogyakarta: Sabda.

Suwito. 1985. Pengantar Awal Sosiolinguistik Teori dan Praktik. Surakarta: Henary Offset. 